\title{
The health worker motivation and competence in the utilization of MCH handbook In Bireuen District
}

\author{
Yuliana Diah ${ }^{1}$, Zulhaida Lubis ${ }^{2}$, Sri Rahayu Sanusi ${ }^{2}$ \\ ${ }^{1}$ Master Student in Faculty of Public Health, Universitas Sumatera Utara, Medan, Indonesia \\ ${ }^{2}$ Lecturer in Faculty of Public Health, Universitas Sumatera Utara, Medan, Indonesia \\ Email: yulianadiah203@gmail.com
}

\begin{abstract}
:
Book maternal and child health $(\mathrm{MCH})$ is a program to improve the quality of health services for mothers and children in order to realize the degree of public health. This study aimed to analyze the motivation and competence of health personnel in the use KIA book in Bireuen district. This research method is qualitative phenomenological approach with a number of informants were 21 people including 4 coordinators KIA, 4 head of public health centers, 4 midwives village health centers, one business and one Kasie Nutrition district MCH / Nutrition. Data retrieval techniques such as interview, recording equipment, stationery, note in the field. The results of the research to get the motivation and competence of health personnel in the use KIA book and presents examples of how to use KIA book as the main media in promotive and preventive give effect to pregnant women and mothers in the use KIA book. The conclusion of this study is the motivation and competence of health personnel in the conduct promotive and preventive efforts on pregnant women and mothers through the use KIA book. This study will provide advice on how to increase the utilization of KIA book as a medium in promotive and preventive efforts for health workers to improve their knowledge and willingness of the community to improve community health status in Bireuen district.
\end{abstract}

Keywords:

motivation; competence; utilization; $\mathrm{MCH}$ handbook

\section{Introduction}

The degree of public health are very closely related to the Maternal Mortality Rate (MMR) and Infant Mortality Rate (IMR), which is the main target in the National Long-Term Development Plan (RPJMN) 2015-2019 health sector, namely enhancing the health and nutritional status of mothers and children. (Presidential Decree No. 2, 2015).

Mothers and children are the groups most vulnerable to various health problems such as pain, nutritional disorders that often ends with kecatatan and death resulting in increased independence of the family in order to maintain the health of mothers and children is the main program of the Ministry of Health (MOH and JICA, 2009), Efforts are being made to realize the independence of the family in maintaining the health of mothers and children is through the use KIA book for enhancing knowledge and skills of the family as a means of promotion and prevention in order to reduce morbidity and mortality in mothers and children.

In the $\mathrm{MCH}$ handbook there is an explanation about the standard of antenatal care, danger signs of pregnancy, signs of labor, care of infants and toddlers, early detection of infant growth, and immunization, and then through the book KIA families can improve the knowledge of pregnant women and families about the health of mothers (pregnant, childbirth, and postpartum) and babies (newborn to age 6 years) as well as information about how to care for maternal and child health. (MOH, 2016) 
Implementation of a policy or program in achieving its objectives need to involve all the components to be actors in the implementation of activities such as components of the organization, procedures, and techniques that realize the expected goals (Ayuningtyas, 2014). Support infrastructure and human resource capacity both financially and is needed in the process of implementing a guarantee the implementation of activities to achieve the expected outcomes. (Ayungnityas, 2014).

One capacity that support the objectives of an organization is its human resources. Human resources by Wake (2012) is one of the important resources within the organization to achieve its goals that make the role of humans as the competitive power that can distinguish it from other organizations. The human resources include health professionals. Predisposing factors in the delivery of health services consisting of the human factor is the willingness and ability of individuals to carry out their duties. The efforts made by the individual in the form of persistence and consistency is the motivation of the individual who is a strength and direction in achieving organizational goals (Robbins, 2015)

The theory of motivation as the basis for the conduct of the leaders in the field including the Theory $\mathrm{X}$ and Theory $\mathrm{Y}$ of Douglas McGroger this theory gives insight on two different viewpoints is a positive angle is a negative angle theory $\mathrm{X}$ and theory $\mathrm{Y}$. Below are the $\mathrm{X}$ theory believe that at basically people do not like the work that needed referral or compulsion to do its job, in turn under the theory of $\mathrm{Y}$ states that workers view work as natural so that on average they can learn and work to accept and even responsible for the job.

Furthermore, two-factor theory by Hetzberg leads to satisfaction and job dissatisfaction. The concept theory suggests that the opposite of satisfaction is discontent, so that this concept can not delete dissatisfaction characteristics of the job does not necessarily make the job satisfying. Furthermore Hertzberg advise and emphasize on the factors related to the work itself or with results that can be obtained directly from the job, such as the opportunity to be promoted, personal growth opportunities, recognition, responsibility, and achievement. Research conducted by Elly Nur on KIA book as material utilization counseling in antenatal care performed by a health center midwife showed that there is a significant relationship with the motivation variable use KIA book by a midwife clinic. Likewise, the research conducted by Faridah (2015) that the effect of the strong motivation of health workers will provide a big boost to pregnant women by 2.5 times in the use KIA book.

Further research conducted by Nawawi on health worker motivation influence on outcomes puskesmas performance is significantly great effect in the amount of 0.60 (standard deviation). In harmony with the results of research conducted by Farida (2015) that support good health worker will encourage mothers 2.5 times the size in the utilization of KIA book. While research on the motivational factor midwife in charge of compliance KIA book an obstacle to the low utilization of KIA book that is only $2.2 \%$ in use by health professionals (midwives) in the utilization of KIA book (Sistiarani, 2014)

\section{Research Method}

The method of research is a qualitative phenomenological approach. The research was conducted in four health centers in remote and very remote working area of Bireuen district, by taking samples or indept interview were 21 informants. Sampling techniques atun informants with purposive sampling technique with particular consideration for the instrument in this study are researchers themselves (human instrument) by holding on 
guidelines open questionnaire (guied questionnaire), where interviews with the informant conducted face to face, with a guided questionnaire prepared basis. Open as well as notebooks and recorders. Technical analysis of the data was descriptive analytic techniques starting from describing the characteristics of informants, categorizing the data to be summarized in matrix form until the conclusion of the analyzed data.

\section{Result and Discussion}

\subsection{Characteristics Needs}

Many contributing factors to look for health care could be realized if the perceived benefits for the individual, the meaning is the basic factor is the direct cause of the need for individuals to seek and do it. Based on the results of interviews with 21 informants representing the working area of Bireuen district in the implementation of KIA book as part of one of the government's efforts in improving knowledge of mothers, families and communities to change attitudes and behaviors about the health of mothers and children. Each informant said that the use KIA book is done and has been the KIA program that automatically they have to carry out the policy.

In the description above, optimalizer implementation of the utilization of KIA book starting from the factor of health personnel in preparing activities such as defining target pregnant women, logistics KIA book, preparations in the promotion of the use KIA book as well as the schedule of class mother and Posyandu, although it did not rule out their views and needs another in optimizing the implementation of the use KIA book. This is like saying mothers as follows: "There is nothing to do other than just weigh".

And further revelation: "never see., With a laugh, come take a book KIA, return on enter again into the paper crackle hanging on the bedroom door and coming up next month taken again, and so on, do not be said for at baca2 at home.

Characteristics of society indirectly be factors that support or hinder the implementation of activities. Social status, social status of the majority of low- and middledyeing situation in the region is very isolated population with the majority of them are farmers and low level of formal education. Lack of education and the level of public awareness for healthy living and maintaining a healthy family to be a phenomenon that often occurs in people in very remote areas.

The number of health problems experienced by people in remote areas to make the government through programs that support in improving health, otherway through the use KIA book done in 1993 to support the peningatan knowledge society and as a medium for health personnel in documenting the health of the mother pregnant, babies and toddlers.

Results of research on the utilization of KIA book performed by health workers in the use KIA book that can improve the health knowledge of pregnant women and mothers about health. Power factor health into one of the supporters in the effort to improve health public status which includes the motivation and competence of health professionals will have an impact on the views and needs of the community against the use KIA book. In line with research conducted by by Faridah (2015) that the effect of the strong motivation of health workers will provide a big boost to pregnant women by 2.5 times in the use KIA book. 


\subsection{The Influence of Power Motivation to Use KIA Book}

There are many factors that cause health workers to increase the motivation to do the job. Factors that cause itself consists of its own individual characteristics, and low sense of awareness and ownership of the job responsibilities. Besides the support of the leadership, guidance and supervision of program managers should also be improved. If the supervision and guidance of both program managers and district health centers are not up to then use KIA book only used as a recording material without being able to be made as media promotive and preventive improved its level of public health. Knowing the job duties into sections to be considered given will be able to find out anything needs to be done in providing services.

The service standards of midwifery care and the care of infants and toddlers conducted by health workers such as standard antenatal care, care early detection of infant growth, immunization and others listed in the book KIA and used as a medium for recording and information for both health professionals and the public (Ministry of Health, 2016).

From the interview, know the motivations and competence of health professionals in the use KIA book presented from several transcripts of interviews them is the motivation of health personnel in performing his job duties as village midwives statement: "Because they thought I was just helping childbirth course, for other services fifty-fifty" And also the midwife statement is "to provide information only briefly."

As well as factors that make the routine job bored in providing services, such as the revelation of a village midwife: "The problem is boredom factor, to explain because it's it". Other factors such as responsibility to work into parts that need to be noticed as the following statement KIA coordinator: "When there is village built, bides assume it is not their area of responsibility"

Looking at the phenomenon of the informant statements when viewed from some theories of motivation can be interpreted that the viewpoint of theory $\mathrm{X}$ and theory $\mathrm{Y}$ that states basically they do not like the job therefore necessary coercion or landing in performing their duties from the standpoint negative.

Good motivation to be able to give a good performance as research conducted by Elly Nur on KIA book as material utilization counseling in antenatal care performed by a health center midwife showed that there is a significant relationship with the motivation variable use KIA book by a health center midwife.

Likewise, the research conducted Viewed in theory that the motivation factor is a potential factor in influencing the performance of the organization in providing services to the community including health care because of talk about motivation not just as part of their efforts to work hard, but motivation is seeing the standpoint of the abilities and confidence in achieving predetermined goals (Robbins, 2015). As a statement of $\mathrm{MCH}$ coordinator expressed about the motivation of midwives in manage service activities are: "Lack of preparation of midwives in preparing activities, lack of motivation of midwives as in carrying less material gain knowledge of pregnant women".

The influence of motivation can have an impact on the achievement of performance results of organizations such as the results of research conducted by Nawawi on health worker motivation influence on outcomes public health center performance is significantly great 
effect in the amount of 0.60 (standard deviation). In harmony with the results of research conducted by Farida (2015) that support good health worker will encourage mothers 2.5 times large in the use KIA book.

\subsection{Competence Influence Health Personnel in the Use KIA Book}

At the time of the interview seen the expression of informants to the question about what is being done during the preparation kegaiatan to completion, the result is known is "do not know about the guidelines in the use KIA book, about what are the conditions of use KIA book, with a facial expression confused and laugh embarrassed.

Furthermore, the statement by the Head of the District Nutrition KIA states that: "Communication is less effective than delivering a message (midwife) and the receiver of the message (the cadre) to carry out their job duties. Tdak information so that the right target". Likewise, in the revelation of the competencies that must be done in accordance with the technical instructions in the use KIA book is, as the village midwife statement as follows: "There is also sure to be noted".

In the guidelines KIA book stated that the completeness of recording in the books of the KIA is bagain essential for monitoring the health of the mother and child, and this is an important part in the use KIA book to the maximum, as research conducted by Sistiarani, 2014 at motivational factors midwives in compliance charging KIA book an obstacle to the low utilization of KIA book that is only $2.2 \%$ in use by health professionals (midwives) in the utilization of KIA book

Utilization of KIA book that has socialized and undertaken since 1993 is the basis of the objectives in reducing maternal and infant mortality rates and increased knowledge through empowerment of families and communities towards the better. Ripley and Franklin in Winarno (2008) argues that the implementation of a policy that has set output or authority must provide the program with a real input and program objectives expected by the government and officials.

\section{Conclusion}

$\mathrm{MCH}$ handbook is one of the Government's aim to increase public knowledge so that they can maintain the health of their families through educational information contained in the books of the KIA. Furthermore, through the use KIA book is good and right will be a documentation of the medical history of pregnant women, infants and young children as part of the monitoring of health status and become an advanced information for other referral agencies such as hospitals.

Based on the information and data obtained in the field, researchers noted several issues that can be repaired and further development, among others:

1. Population characteristics so remote a part that needs great attention, lack of education, low social status of the majority of farmers made no factor to their needs so that they will get to do it.

2. The need for awareness of health personnel in performing their duties that is part of the responsibilities of the job to be done without fed.

3. The need for supervision and oversight of the management of a more serious program to raise awareness in the use KIA book as a medium of education for the public information 


\section{Reference}

Arikunto, Suharsini. 2006. Research Procedure A Practical Approach. Rineka Reserved. Jakarta

Budianto, E. 2012. Biostatistics for Medical and Public Health. ECC medicine book publisher. Jakarta

Ministry of Health. 2009. General Guidelines for Management. Book Publishing KIA, the Ministry of Health.

MOH. Indonesia Health Profile 2015. www.depkes. go.id/resources/download/pusdatin /Profil-Kesehatan-Indonesia-2016.pdf

MOH. 2016. Maternal and Child Health Handbook. The Ministry of Health and JICA. Jakarta

Dudi Zulfadi. 2014. Ethics and Midwifery Management. Jaya Science. Yogyakarta.

Endang Purwoastuti, Elisabeth, S. 2015. Science Sodial for Obstetrics Gynecology Obstetrics. New Library Press. Yogyakarta.

Ida Bagus. Capita Selecta 2005. Routine Management Obstri Gynecology and KB. Medical books EGC. Jakarta.

Ika Fitria Elmida \& Siska Firdaus. 2014. Basic Skills Midwifery. CV Trans Media Info. Jakarta.

The Ministry of Health, Republic of Indonesia. (2015). Technical Instructions use of maternal and child health books. Jakarta: Ministry of Health and JICA (Japan International Coorperation Agency).

$\mathrm{MoH} \quad$ RI. 2017. Performance Achievement MoH RI 20152017.http://www.depkes.go.id/article/print/17081700004/-inilah-capaian-kinerjakemenkes-ri-tahun-2015--2017.html

MoH, RI., 2018. Main results Riskesdas 2018. Jakarta. Agency for Health Care Research and Development.

Kusmiyati, Y. 2010. Pregnancy care. Titramaya. Yogyakarta.

Kusmiati, et al. 2008. The Complete Guide to Pregnancy Care. Fitramaya. Yogyakarta.

Manuaba. 2008. Emergency Obsetetri Obtetri Gynecology Gynecology \& Social For Professional Midwives, Medical Book EGC. Jakarta.

Mufdlilah. 2009. Focused Antenatal Care. Yogyakarta: Nuha Medika

Maryunani, A., Paulina, E. 2017. Maternal and Neonatal Emergency Care. Health Books. East Jakarta.

Purwoastuti, E., Siwi Walyuni, E. 2015. Quality of Health Services and Obstetrics. New Library Press. Yogyakarta.

Robbins, SP, \& Judge, TA (2015). Organizational behavior. Jakarta: Four Salemba.

Riani, AL (2011). Organizational culture. Yogyakarta: Graha Science.

Sihotang, Havija., Santosa, Heru., \& Salbiah., Relationship supervision function with labor productivity runagan head nurse at the General Hospital Medan Pirngadi

Sugiyono. (2016). Research methods combined (mixed mthods). Bandung: Alvabeta

IDHS. 2001. Health Care System related

Indonesia.https://media.neliti.com/media/publications/66010-ID-penyebab-

kematian-bayi-baru-lahir-neonat.pdf

Subarsono, AG. 2010. Public Policy Analysis. Student Reader. Yogyakarta.

Sabri, L., Priyo Hastono, S. 2010. Health Statistics. King Grafindo Persada. Jakarta.

Tampilang, Ram, Marnex., Tuda, JSB, and Waraow, Herman. Supervising relations with satisfaction perawatn chief executive rooms in hospitals Lingkendage Tahuna

Winarno, Budi., (2008). Public policy theory and process, Jakarta. PT Book We 